REVIEW

\title{
Management of Graves' hyperthyroidism in pregnancy: focus on both maternal and foetal thyroid function, and caution against surgical thyroidectomy in pregnancy
}

\author{
Peter Laurberg, Claire Bournaud ${ }^{1}$, Jesper Karmisholt and Jacques Orgiazzi ${ }^{2}$ \\ Department of Endocrinology and Medicine, Aalborg Hospital, Aarhus University Hospital, DK-9000 Aalborg, Denmark, ${ }^{1}$ Department of Nuclear \\ Medicine, Université Lyon 1, Hospices Civils de Lyon, Lyon, France and ${ }^{2}$ Department of Endocrinology, Université Lyon-1, Centre Hospitalier Lyon-Sud, \\ Lyon, France \\ (Correspondence should be addressed to P Laurberg; Email: peter.laurberg@rn.dk)
}

\begin{abstract}
Graves' disease is a common autoimmune disorder in women in fertile ages. The hyperthyroidism is caused by generation of TSH-receptor activating antibodies. In pregnancy both the antibodies and the antithyroid medication given to the mother pass the placenta and affect the foetal thyroid gland. Thyroid function should be controlled not only in the mother with Graves' hyperthyroidism but also in her foetus. The review includes two cases illustrating some of the problems in managing Graves' disease in pregnancy.

Major threats to optimal foetal thyroid function are inadequate or over aggressive antithyroid drug therapy of the mother. It should be taken into account that antithyroid drugs tend to block the foetal thyroid function more effectively than the maternal thyroid function, and that levothyroxin (L- $\left.\mathrm{T}_{4}\right)$ given to the mother will have only a limited effect in the foetus.

Surgical thyroidectomy of patients with Graves' hyperthyroidism does not lead to immediate remission of the autoimmune abnormality, and the combination thyroidectomy + withdrawal of antithyroid medication $+\mathrm{L}-\mathrm{T}_{4}$ replacement of the mother involves a high risk of foetal hyperthyroidism.

Conclusion: Antithyroid drug therapy of pregnant women with Graves' hyperthyroidism should be balanced to control both maternal and foetal thyroid function. Surgical thyroidectomy of a pregnant woman with active disease may lead to isolated foetal hyperthyroidism.
\end{abstract}

European Journal of Endocrinology 160 1-8

\section{Introduction}

Graves' disease is a common autoimmune disorder that may have diverse clinical manifestations. The key pathogenetic element is autoimmunity against the TSH receptor (1), and the most common clinical abnormality is hyperthyroidism caused by TSH-receptor stimulating autoantibodies.

In populations with sufficient iodine intake Graves' disease is the most common cause of hyperthyroidism (2), and $\sim 1 \%$ of pregnant women have been treated before, or are being treated during pregnancy for Graves' hyperthyroidism.

Appropriate management of Graves' disease during the pregnancy is important for the mother's health and for the course of pregnancy. Moreover, the quality of management may have considerable impact on the progeny both in foetal and in neonatal life and on the long-term health of the child.

The present mini-review discusses some of the important considerations in taking care of pregnant women with Graves' disease. A special topic evaluated is the role of surgery with subtotal or total thyroidectomy in pregnant women with active disease.

\section{Graves' disease and pregnancy in various combinations}

Hyperthyroidism and pregnancy may coexist in a patient who becomes pregnant while she is already hyperthyroid or being treated for hyperthyroidism with an antithyroid drug. Less frequently, Graves' disease may develop during pregnancy. Another combination is the occurrence of a pregnancy in a woman with previous Graves' disease, and in this condition, it is of importance to clarify thyroid history.

If the thyroid status of the mother is normal after previous treatment with antithyroid drug only, then no consequence to the foetus is to be anticipated (3). Relapse of the hyperthyroidism may occur during pregnancy, but this is not common. More frequently, recurrence of the hyperthyroidism may occur during the post partum period $(4,5)$. 
On the other hand, if previous Graves' disease has been treated surgically or with radioiodine, and whatever the current status, euthyroid with or without levothyroxin $\left(\mathrm{L}-\mathrm{T}_{4}\right)$ substitution, the pregnant woman may still harbour circulating antibodies against the TSH-receptor (TRAb). Hence, the foetus may be at risk for thyroid dysfunction because maternal antibodies pass the placenta (3).

Thyroid surgery for Graves' disease is in most patients followed by a gradual disappearance of TRAb from circulation (similar to the effect of therapy with antithyroid medication), whereas radioiodine therapy is often followed by an immediate worsening of autoimmunity with an increase in TRAb in serum (6-8). The duration of this worsening is about 1 year, and it is normally followed by a subsequent gradual fall in the levels of TRAb in serum. However, even 5 years after radioiodine therapy many patients are still TRAb positive (8).

Thus, depending on the serum level of TRAb, it may be relevant to advise women to postpone pregnancy for more than the usual 4-6 months (for reason of radioprotection) after radioiodine therapy to prevent the risk of thyroid dysfunction in the foetus. Even if the risk of high TRAb in the mother is in general lower after thyroid surgery than after radioiodine therapy (8), similar considerations may be relevant after surgical thyroidectomy for Graves' hyperthyroidism.

\section{Risks and complications from Graves' hyperthyroidism and therapy in the pregnant woman}

Table 1 gives an overview of some complications associated with untreated Graves' hyperthyroidism in pregnant women as well as some of the consequences of the different types of therapy. The physical burden of untreated or inadequately treated hyperthyroidism added to the burden of pregnancy may precipitate congestive heart failure in the mother, and preeclampsia is a common phenomenon in hyperthyroid pregnant women $(9,10)$. In severe cases, thyroid storm may develop (9-11). Such complications and more direct effects of excess thyroid hormone lead to a high risk of miscarriage, placental abruption and preterm delivery if a pregnant woman is hyperthyroid (12). Accordingly, a primary goal of therapy of Graves' hyperthyroidism in a pregnant woman is to avoid complications to hyperthyroidism in the mother by making and keeping her euthyroid or near euthyroid.

Among the three common types of therapy of Graves' hyperthyroidism, antithyroid medication (propylthiouracil (PTU), methimazole or its prodrug carbimazole), thyroid surgery and radioiodine therapy, the latter is not useable in pregnant women because of the foetal irradiation.

The two therapeutic modalities, antithyroid medication and surgery, can be used to make a pregnant woman euthyroid, but both types of therapy require special subsequent precautions in order to protect the foetus, as described below. In most instances, pregnancy is associated with a progressive decrease in the autoimmune activity of Graves' disease $(13,14)$, so that in women receiving antithyroid medication for Graves' hyperthyroidism before becoming pregnant it is often feasible to gradually reduce the dose or to withdraw the medication $(14,15)$. Occasionally, as reported in a few studies $(16$, 17 ), but not confirmed on a large scale (18), the nature of TRAb may change during pregnancy from stimulation to blocking of the TSH receptor. In such patients not only withdrawal of antithyroid medication, but also therapy of the mother with $\mathrm{L}-\mathrm{T}_{4}$ may be necessary.

Antithyroid medication given as monotherapy is the first line of therapy of Graves' hyperthyroidism in pregnancy. PTU is preferred, at least in the first trimester, because of the small increase in risk of malformations associated with the use of methimazole (19-21). As discussed below and illustrated by the two cases presented, focus on keeping the dose of medication as low as possible is important to protect the foetus against hypothyroidism.

A special case is represented by women who receive $\mathrm{L}-\mathrm{T}_{4}$ replacement therapy after a previous radioiodine therapy or surgical thyroidectomy for Graves' hyperthyroidism (Table 1). Such women will often need an increase in the dose of $\mathrm{L}_{-} \mathrm{T}_{4}$ in early pregnancy, as will other women treated for hypothyroidism (22).

\section{Risks and complications from Graves' hyperthyroidism and therapy in the foetus}

Thyroid hormones are necessary for optimal mammalian foetal and neonatal development, and the risk of malformations may be increased in the newborns to hyperthyroid mothers $(23,24)$. Lack of thyroid hormones for more than a few weeks during vulnerable periods of development involves a risk of permanent cerebral impairment (25). On the other hand, excess amounts of thyroid hormones may lead to growth retardation and accelerated bone maturation, and it is associated with an increase in the risk of foetal death (26). In the brain, local concentrations of thyroid hormone are among other factors dependent on the activity of thyroid hormone activating and inactivating deiodinases. Somewhat unexpected, studies of experimental animals have revealed that congenital defects in the activity of thyroid hormone inactivating enzymes are much more deleterious for normal development and function of the CNS pituitarythyroid axis than the lack of activating enzymes (27).

Thus, it is important when treating Graves' hyperthyroidism in a pregnant woman to focus on keeping physiological amounts of thyroid hormones not only in the maternal but also in the foetal compartment. In the later part of pregnancy, foetal thyroid function can be 
Table 1 Risks and complications from Graves' hyperthyroidism and therapy in pregnancy.

\begin{tabular}{|c|c|c|c|c|c|}
\hline $\begin{array}{l}\text { Graves' disease in } \\
\text { a pregnant woman }\end{array}$ & Mother's health & Pregnancy course & Foetus & Neonate & Infant/child \\
\hline $\begin{array}{l}\text { Untreated or inade- } \\
\text { quately treated } \\
\text { hyperthyroidism }\end{array}$ & $\begin{array}{l}\text { Risk of congestive } \\
\text { heart failure, pre- } \\
\text { eclampsia and } \\
\text { thyroid storm }\end{array}$ & $\begin{array}{l}\text { Risk of miscarriage, } \\
\text { placental abrup- } \\
\text { tion, preterm } \\
\text { delivery }\end{array}$ & $\begin{array}{l}\text { Hyperthyroid (tachy- } \\
\text { cardia, growth } \\
\text { retardation, accel- } \\
\text { erated bone matu- } \\
\text { ration, goiter, risk } \\
\text { of death, malfor- } \\
\text { mations) }\end{array}$ & $\begin{array}{l}\text { Risk of transient } \\
\text { primary hyperthyr- } \\
\text { oidism and tran- } \\
\text { sient secondary } \\
\text { hypothyroidism }\end{array}$ & $\begin{array}{l}\text { Risk of disordered } \\
\text { pituitary/thyroid } \\
\text { axis, thyroid disin- } \\
\text { tegration }{ }^{\mathrm{a}} \text {, malfor- } \\
\text { mations }\end{array}$ \\
\hline $\begin{array}{l}\text { ATD treated, euthyr- } \\
\text { oid without } \mathrm{L}-\mathrm{T}_{4}{ }^{\mathrm{b}}\end{array}$ & & & $\begin{array}{l}\text { Risk of hypothyroid- } \\
\text { ism and goiter } \\
\text { caused by higher } \\
\text { fetal than maternal } \\
\text { sensitivity to ATD }\end{array}$ & $\begin{array}{l}\text { Risk of delayed tran- } \\
\text { sient hyperthyroid- } \\
\text { ism from mother's } \\
\text { TRAb }\end{array}$ & $\begin{array}{l}\text { Small risk of malfor- } \\
\text { mations with } \\
\text { methimazole }\end{array}$ \\
\hline $\begin{array}{l}\text { Surgery }+\mathrm{L}-\mathrm{T}_{4} \text { in } \\
\text { pregnancy }\end{array}$ & & & $\begin{array}{l}\text { Risk of hyperthyroid- } \\
\text { ism from mother's } \\
\text { TRAb }\end{array}$ & $\begin{array}{l}\text { Risk of transient } \\
\text { hyperthyroidism } \\
\text { from mother's } \\
\text { TRAb }^{d}\end{array}$ & \\
\hline $\begin{array}{l}\text { Previous radical } \\
\text { treatment - radio- } \\
\text { iodine or surgery } \\
\text { - plus } \mathrm{L}^{-\mathrm{T}_{4}}\end{array}$ & $\begin{array}{l}\text { Risk of hypothyroid- } \\
\text { ism caused by } \\
\text { increase in need of } \\
{\mathrm{L}-\mathrm{T}_{4}}\end{array}$ & & $\begin{array}{l}\text { Risk of hyperthyroid- } \\
\text { ism from mother's } \\
\text { TRAb }^{\dagger} \text { (risk higher } \\
\text { after radioiodine) }\end{array}$ & $\begin{array}{l}\text { Risk of transient } \\
\text { hyperthyroidism } \\
\text { from mother's } \\
\text { TRAb }^{d} \text { (risk higher } \\
\text { after radioiodine) }\end{array}$ & \\
\hline $\begin{array}{l}\text { Previous ATD now } \\
\text { euthyroid }\end{array}$ & $\begin{array}{l}\text { Risk of relapse of } \\
\text { hyperthyroidism } \\
\text { post partum }\end{array}$ & & & & \\
\hline
\end{tabular}

TRAb, TSH-receptor autoantibodies; ATD, antithyroid drugs (propylthiouracil, methimazole).

a'Thyroid disintegration' is the term suggested for at pattern of developmentally disordered thyroid morphology and function that may be seen in children born of mothers with inadequately treated Graves' hyperthyroidism (52).

${ }^{b}$ Block/replacement therapy (ATD $+\mathrm{L}_{-} \mathrm{T}_{4}$ ) should not be used after week 10-12 of pregnancy, when the fetal thyroid starts functioning (3). The exception from this rule is a pregnant woman with previous Graves' disease treated with thyroid ablative - surgery or radioiodine - therapy and subsequent hypothyroidism substituted with $\mathrm{L}_{4}$. In the case of concurrent high serum concentration of TRAb and signs of fetal hyperthyroidism, administration of ATD to the mother, in addition to $L-\mathrm{T}_{4}$, may be considered.

'Use minimal ATD dose to keep mothers thyroid function around upper normal. If TRAb negative, try to gradually withdraw ATD.

${ }^{\mathrm{d}}$ Risk evaluation from measurement of TRAb in the mother in late pregnancy. If high, monitor neonatal thyroid function.

e It is assumed that $\mathrm{L}-\mathrm{T}_{4}$ replacement to the mother is initiated immediately after surgery and the dose adjusted to keep the mother euthyroid.

${ }^{\mathrm{f}} \mathrm{Risk}$ evaluation from measurement of TRAb in mother in early pregnancy. If TRAb is high, monitor foetus for goiter, growth restriction and tachycardia.

studied directly by performing thyroid function tests on blood obtained by cordocentesis (28). However, cordocentesis carries a $1-2 \%$ risk of foetal loss (29), and in the vast majority of women it is possible to judge foetal thyroid function with sufficient precision without having to perform cordocentesis. Table 1 shows how the foetus may be affected by Graves' hyperthyroidism in the mother and by therapy, and Table 2 shows some of the factors that are important for the balance between maternal and foetal thyroid function in Graves' hyperthyroidism.

The importance of normally not using block-replacement therapy (PTU $\left.+\mathrm{L}-\mathrm{T}_{4}\right)$ after week 10-12 of pregnancy as indicated in Tables 1 and 2 is illustrated by the following email received August 2008 from a Dutch woman who had found a previous discussion of management of Graves' disease in pregnancy on the internet:

\section{Dear Mr Laurberg,}

Before my pregnancy I was diagnosed with hyperthyroidism. My doctor prescribed PTU three times $100 \mathrm{mg}$ daily and $\mathrm{T}_{4}$. During my pregnancy the treatment remained the same. My values of TSH and $T_{4}$ were very good. I did have my doubts about the high dosage of PTU, but he assured me that it was just fine.
My daughter was born in September 2007. She was born with severe hypothyroidism, a large struma and an MRI showed a lot of fluid in her brain. We were in shock.

She is now doing very well, but we have a feeling that her condition was caused by my high doses of PTU. Is that possible?

\section{Kind regards,}

XXX

This is the experience of a patient, and the authors have had no access to the files of the patient.

Stimulating TSH-receptor antibodies leading to Graves' hyperthyroidism in the pregnant woman pass the placenta, as do thyroid hormones to a limited degree, and in general, if the mother suffers from untreated Graves' hyperthyroidism it can be assumed that the foetus is hyperthyroid.

Antithyroid drugs also pass the placenta, and therapy of the maternal hyperthyroidism is also therapy of the foetal hyperthyroidism. However, antithyroid drug therapy tends to be more effective in the foetus than in the mother (15). Accordingly, when the mother is euthyroid on antithyroid drug therapy it is important to be aware of the risk for foetal hypothyroidism (Table 1) as illustrated by case 1 . 
Table 2 Graves' hyperthyroidism in pregnancy and the balance between maternal and foetal thyroid function.

i) TSH-receptor stimulating antibodies produced in the mother and inducing maternal hyperthyroidism pass the placenta, and they stimulate the foetal thyroid

ii) If the mother has an intact thyroid, her thyroid function mirrors the thyroid function of the foetus

iii) Antithyroid drugs (propylthiouracil and methimazole) pass the placenta and induce a block of both the maternal and the foetal thyroid hormone production

iv) At a given dose of propylthiouracil or methimazole the block of the foetal thyroid is more effective than of the maternal thyroid

v) During antithyroid drug therapy the thyroid function of the mother should be kept around or slightly above upper normal to avoid foetal hypothyroidism in the last part of pregnancy

vi) Thyroid hormones only pass the placenta barrier to a very limited degree

vii) A combination of antithyroid drug and $L-\mathrm{T}_{4}$ given to the mother to keep her euthyroid (block + replace therapy) may mask foetal hypothyroidism induced by the antithyroid drugs

viii) The combination of block (of the foetal thyroid) + replacement (of the hypothyroid mother) is only appropriate in a hypothyroid mother (after previous surgery or radioiodine therapy for Graves' hyperthyroidism) with a hyperthyroid foetus from persistent maternal production of $\mathrm{TSH}$-receptor stimulating antibodies

ix) Appropriate dosing of antithyroid drugs to keep the foetus euthyroid in an athyreotic mother with active Graves' disease is difficult, and the situation is best avoided if possible

\section{Case 1}

A 29 year-old woman had repeated episodes of relapsing hyperthyroidism since the age of 13 years. She had been on and off antithyroid drugs several times, but the thyroid function had been stable on antithyroid drug therapy for the last 2 years. During the current uncomplicated pregnancy the patient received therapy with PTU $100 \mathrm{mg} \times 4$ /day and was euthyroid. At week $19+4$ days of pregnancy foetal ultrasonography gave suspicion of a foetal goitre, and when ultrasonography was repeated at week 23, this revealed a rather large (7 ml) foetal goitre. Acute cordocentesis (week 23) showed a foetal serum TSH of $>200 \mathrm{mU} / \mathrm{l}$ (reference at week 20 around $3-4 \mathrm{mU} / \mathrm{l}(30,31)$ ) and $\mathrm{L}_{-} \mathrm{T}_{4}(50-$ $100 \mu \mathrm{g}$ ) was administered into the maternal amniotic fluid on a total of four occasions over 1 month. At the time of the cordocentesis, the mother had a serum TSH of $2.5 \mathrm{mU} / \mathrm{l}$ (reference $0.3-4.5 \mathrm{mU} / \mathrm{l}$ ), total $\mathrm{T}_{4}$ was $75 \mathrm{nmol} / \mathrm{l}$ (reference: $90-210 \mathrm{nmol} / \mathrm{l}$ at this phase of pregnancy), total tri-iodothyronine $\left(\mathrm{T}_{3}\right)$ was $2.7 \mathrm{nmol} / \mathrm{l}$ (reference: $1.8-4.0 \mathrm{nmol} / \mathrm{l}$ at this phase of pregnancy). She was clinically euthyroid, but she had a large goitre (171 ml by ultrasonography) with some vascular sounds. There were no measurable TSH-receptor antibodies in serum $(<0.3 \mathrm{U} / \mathrm{l}$, reference $<1.0 \mathrm{U} / \mathrm{l}$, DYNOtest TRAK human, BRAHMS, Berlin, Germany). Based on the assumptions that the foetal hypothyroidism and goitre were caused by the relatively high dose of PTU given to the mother, that the maternal Graves' disease was in remission, and that the relative resistance of the mother to PTU was caused by her large amount of thyroid tissue, the dose of PTU was reduced from 400 to $50 \mathrm{mg} /$ day, and at week 32 of pregnancy PTU was withdrawn. At week 32 the maternal serum TSH was $0.3 \mathrm{mU} / \mathrm{l}$, total $\mathrm{T}_{4}$ was $143 \mathrm{nmol} / \mathrm{l}$, total $\mathrm{T}_{3}$ was $3.5 \mathrm{nmol} / \mathrm{l}$ and the maternal goitre size had decreased to $127 \mathrm{ml}$. The foetal goitre disappeared. At delivery (week 40) cord serum TSH was normal (5.4 mU/l) and serum TSH in the neonate at day 5 was $3.0 \mathrm{mU} / \mathrm{l}$.

Four months after the delivery the mother had clinical and biochemical relapse of Graves' hyperthyroidism and TRAb increased to $26 \mathrm{U} / \mathrm{l}$. After a course of antithyroid drug therapy + potassium iodide for 10 days, surgical total thyroidectomy was performed with the removal of $401 \mathrm{~g}$ goitre.

Apparently, too little attention had been paid to the absence of TRAb and also to the lack of increase in serum total $\mathrm{T}_{4}$ during the first half of pregnancy in this patient. In the early part of pregnancy serum total $\mathrm{T}_{4}$ and total $\mathrm{T}_{3}$ increase gradually in parallel with the increase in serum thyroid hormone binding globulin (32). As a practical measure, the reference ranges for total $\mathrm{T}_{4}$ and $\mathrm{T}_{3}$ can gradually be adjusted from week 7 to 16 of pregnancy with an increase in both low and high limits of reference with $5 \%$ of non-pregnant values per week. After week 16, the reference ranges are $\sim 50 \%$ higher than non-pregnancy ranges until delivery (32). It may be speculated that the low serum $\mathrm{T}_{4}$ in the mother contributed to the high-foetal serum TSH, but the main factor is undoubtedly blocking of the foetal thyroid by PTU.

Case 1 illustrates the importance of trying to reach the minimal dose of antithyroid drugs during pregnancy and to stop medication whenever it is possible provided serum TSH in the mother is not low, and especially if the mother becomes TRAb negative. In case 1 , the foetal goitre was caused by excessive foetal TSH secretion in response to drug induced foetal hypothyroidism. Many similar cases have been published (33-42), and often it is not necessary to perform cordocentesis to make the diagnosis.

Case 2 is a more complicated patient where both maternal TRAb and foetal TSH may have participated in the generation of foetal goitre, and where measurement of TSH in cord blood obtained by cordocentesis was necessary to differentiate the two causes of foetal goitre.

\section{Case 2}

A 29 year-old woman had new Graves' disease with hyperthyroidism, mild orbitopathy and diffuse goitre 
diagnosed at week 19 of pregnancy. Therapy with PTU (initial dose $100 \mathrm{mg} \times 3 /$ day) + propranolol led to clinical and biochemical normalization. At gestational week 29, serum TSH and $\mathrm{fT}_{4}$ being in the normal range, therapy was inadvertently withdrawn. Resumption of hyperthyroidism occurred a few weeks later. At week 32, after 1 week of PTU therapy ( $50 \mathrm{mg} \times 3 /$ day) serum $\mathrm{fT}_{4}$ was $30.7 \mathrm{pmol} / \mathrm{l}$ (reference $10-26 \mathrm{pmol} / \mathrm{l}$ ), $\mathrm{fT}_{3}$ was $22.9 \mathrm{pmol} / \mathrm{l}$ (reference $3-7 \mathrm{pmol} / \mathrm{l}$ ) and TSH was $<0.05 \mathrm{mU} / \mathrm{l}(0.5-4.8 \mathrm{mU} / \mathrm{l})$. Maternal TRAb was high at $99 \mathrm{U} / \mathrm{l}$ (reference $<10 \mathrm{U} / \mathrm{l}$, TRAK assay, BRAHMS), and the thyroid stimulating activity was high (1396\% of reference in a bioassay (43)). The dose of PTU was temporarily increased to $300 \mathrm{mg} /$ day and subsequently fluctuated between 150 and $250 \mathrm{mg}$ /day according to $\mathrm{fT}_{4}$ and $\mathrm{fT}_{3}$ levels.

Sonographic evaluations of the foetus had been normal, but at week 33 of gestation an enlarged foetal thyroid measuring $40 \times 17 \mathrm{~mm}$ (maximal length $\times$ maximal width) was observed. One week later the goitre had increased, leading to cervical spine extension. Foetal biometry and activity were normal. Foetal heart rate was $142 / \mathrm{min}$. Cordocentesis was performed at week 34 to further evaluate the cause of the goitre. Foetal thyroid function tests were: TSH $4.3 \mathrm{mU} / \mathrm{l}$ (normal for gestational age) $(30,31), \mathrm{fT}_{4} 4.0 \mathrm{pmol} / \mathrm{l}$, $\mathrm{fT}_{3} 3.1 \mathrm{pmol} / \mathrm{l}$ and tests in the mother showed $\mathrm{TSH}$ $<0.05 \mathrm{mU} / \mathrm{l}, \mathrm{fT}_{4} 5.4 \mathrm{pmol} / \mathrm{l}, \mathrm{fT}_{3} 7.9 \mathrm{pmol} / \mathrm{l}$. TRAb was $120 \mathrm{U} / \mathrm{l}$ in the mother and $60 \mathrm{U} / \mathrm{l}$ in the foetus. The dose of PTU was subsequently reduced to $150 \mathrm{mg} /$ day, and this was continued throughout pregnancy. In the mother $\mathrm{fT}_{3}$ normalized, and $\mathrm{fT}_{4}$ remained low.

Repeated ultrasonographical investigations of the foetus showed further enlargement of the thyroid (week 36: right lobe $32 \times 12$, left lobe: $37 \times 25 \mathrm{~mm}$; week 39: right lobe $48 \times 28$, left lobe $40 \times 21 \mathrm{~mm}$ ) and at week 39 of gestation an uncomplicated caesarean section was performed. The newborn (weight $3970 \mathrm{~g}$ ) presented normal except for a large goitre (neck circumference $24 \mathrm{~cm}$ ). At the time of delivery, thyroid function tests in the mother were TSH $<0.05 \mathrm{mU} / \mathrm{l}$, $\mathrm{fT}_{4} 4.4 \mathrm{pmol} / \mathrm{l}, \mathrm{fT}_{3} 6.7 \mathrm{pmol} / \mathrm{l}$, and tests in the neonate (cord blood) were TSH $33.7 \mathrm{mU} / \mathrm{l}$ (reference in cord blood 2.5-25 mU/l (44, 45), $\mathrm{fT}_{4} 2.2 \mathrm{pmol} / \mathrm{l}(10-18 \mathrm{pmol} / \mathrm{l}$ (44, $45)), \mathrm{fT}_{3} 4.1 \mathrm{pmol} / \mathrm{l}$. TRAb was $62 \mathrm{U} / \mathrm{l}$ in the mother and $65 \mathrm{U} / \mathrm{l}$ in the neonate.

At day 6 the newborn showed signs of hyperthyroidism with tachycardia, hyperexcitability, erythema and mild cardiac failure. TSH was $0.9 \mathrm{mU} / \mathrm{l}$, $\mathrm{fT}_{4}$ was $23.5 \mathrm{pmol} / \mathrm{l}, \mathrm{fT}_{3}$ was $42 \mathrm{pmol} / \mathrm{l}$, TRAb was $54 \mathrm{U} / \mathrm{l}$ and antithyroid drug therapy had to be instituted and maintained for 15 weeks.

After delivery, maternal PTU treatment was increased to $600 \mathrm{mg} /$ day, and 3 months after a total thyroidectomy was performed with removal of $95 \mathrm{~g}$ goitre. The patient was well on $\mathrm{L}_{-} \mathrm{T}_{4}$ replacement therapy and 3 years later she went through a pregnancy without complications.
In this case, the foetal goitre observed at week 34 of gestation was caused by TRAb stimulation, as TSH in the foetus was not elevated. On the other hand, the increase in foetal thyroid size in late pregnancy had probably been caused by a combination of stimulation by high levels of TRAb from the mother and elevated foetal TSH secretion. Evidently, the mother had Graves' disease with a severe autoimmune disturbance, and it was difficult to balance therapy between maternal hyperthyroidism and foetal hypothyroidism.

Both cases illustrate the usefulness of a combined use of thyroid function testing including measurement of TRAb and ultrasonography of the foetus for monitoring of pregnancy in women with Graves' disease. Ultrasonography of the foetus from mid-gestation is necessary for evaluation of foetal thyroid volume (Fig. 1) as well as foetal development in the women at risk of foetal thyroid dysfunction $(40,46)$. Women at risk are characterized by either the need of a high dose of antithyroid drug or the presence of high-serum levels of TRAb (42).

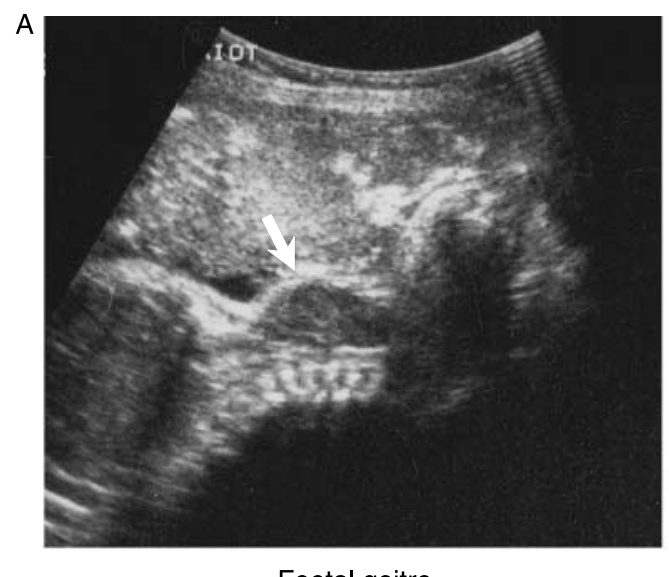

Foetal goitre

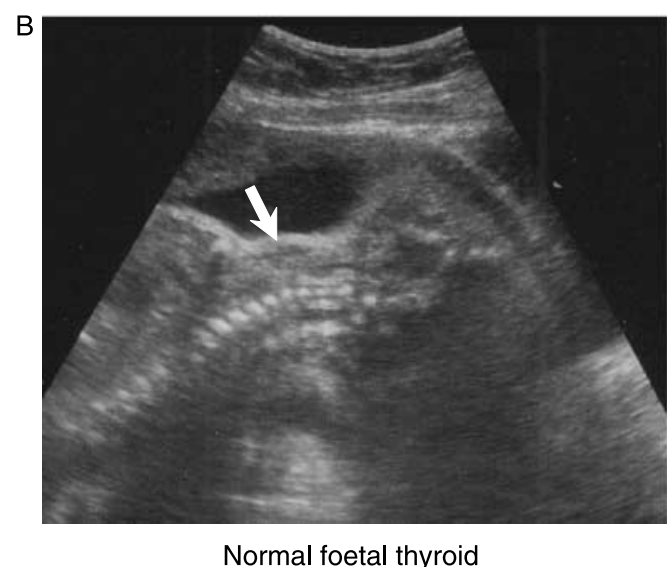

Figure 1 Ultrasonographical goitre in the foetus of case 2 in relation to Graves' disease in the mother $(\mathrm{A})$. For comparison a normal foetal thyroid in a normal pregnant woman is shown in (B). Courtesy of Dr Devonec. 


\section{The spectrum of management of severe Graves' disease with predictable trans- placental passage of thyroid stimulating antibodies}

Before week 10-12, when the foetal thyroid hormone production becomes functioning, the transplacental passage of thyroid stimulating antibodies from the mother has no importance for thyroid hormone levels in the foetus. However, after week 12 the foetal thyroid will gradually develop to respond to the stimulation and the foetus may at some point become hyperthyroid, unless therapy is given.

If left untreated, the hyperthyroidism will be present at the time of birth, and it may last for several months because the maternal antibodies are only cleared slowly, half-life averaging 3 weeks, from the circulation of the neonate. The consequences of foetal and neonatal hyperthyroidism may be severe (Table 1).

If appropriate antithyroid drug therapy is given to the mother, this will keep the foetus euthyroid until birth. After birth the antithyroid drugs from the mother will disappear from the foetal circulation and thyroid within the first days, and after some delay, neonatal hyperthyroidism may develop until the maternal antibodies are cleared (26). High-serum levels of maternal TSHreceptor antibodies in late pregnancy indicate a risk of neonatal hyperthyroidism (3). This complication is illustrated in case 2 .

During the period of foetal and neonatal hyperthyroidism the pituitary TSH secretion has been suppressed and the phase of neonatal hyperthyroidism may be followed by a phase of secondary hypothyroidism, until pituitary TSH secretion is restored (47).

If the pregnant woman has previously received ablative treatment for Graves' hyperthyroidism by thyroid surgery and especially by radioiodine as discussed above, the mother may still be producing thyroid stimulating antibodies (8). A test for the presence of TRAb in serum should be performed before the second half of pregnancy (3). If positive, the foetus should be followed carefully for signs of thyroid dysfunction.

Case 2 illustrates the difficulty of balancing antithyroid medication in a pregnant patient with active disease. In such a patient, surgical thyroidectomy in the second trimester of pregnancy might be considered, as has been recommended in women who need persistently high doses of antithyroid drugs to control Graves' hyperthyroidism (48).

There is little published evidence to indicate whether the recommended strategy of thyroid surgery (48) is optimal or not, and accordingly no evidence-based recommendations can be given. However, TRAb disappears slowly after surgical thyroidectomy, with only about half of the patients being TRAb negative after a year (8). This means that even if the pregnant woman becomes euthyroid after surgery + withdrawal of antithyroid medication $+\mathrm{L}-\mathrm{T}_{4}$ administration, the foetus may be hyperthyroid from maternal TRAb. In one of the published cases of isolated foetal hyperthyroidism, the mother had undergone thyroid surgery for Graves' disease only 2 months before becoming pregnant (49), thus coming close to the situation of thyroidectomy during pregnancy.

Thus, we recommend that surgical thyroidectomy of a pregnant woman with Graves' disease is only performed in case of uncontrollable hyperthyroidism that threatens the health of the woman, or when antithyroid drugs are not tolerated. If thyroidectomy is performed, this should be followed by a systematic and careful follow-up evaluation of the thyroid state of the foetus.

In case of isolated foetal hyperthyroidism after thyroid ablation in the mother, this might be treated by administering antithyroid medication to the mother in combination with the $\mathrm{L}-\mathrm{T}_{4}$ replacement started after the ablation. The experience with such therapy is limited and a close monitoring of the foetus is necessary. In a review of 11 anecdotal reports of antithyroid drug therapy given to mothers for isolated foetal hyperthyroidism, all the mothers had received ablative therapy for Graves' hyperthyroidism before becoming pregnant (50). Outcomes were better after therapy than in pregnancies where these women had not been treated with antithyroid drugs. Future results of prospective monitoring and therapy of foetal hyperthyroidism after maternal thyroidectomy during pregnancy should be published to accumulate experience and evidence.

In conclusion, thyroid function should be controlled not only in the pregnant woman with Graves' hyperthyroidism but also in her foetus. This is necessary to diminish the risks to the mother, to increase the likelihood of a successful outcome of the pregnancy, and to minimize the risk to the child. Recent studies have suggested that children born of inadequately treated hyperthyroid mothers have a risk of more prolonged, maybe even permanent developmental disruption of hypothalamic-pituitary-thyroid function $(51,52)$, that may correspond to the developmental abnormalities observed in animals with lack of type 3 deiodinase (27). Insufficient or over aggressive antithyroid drug therapy of the mother or a failure of recognizing and treating TRAb-induced foetal hyperthyroidism in a mother with no functional thyroid gland are major threats to optimal foetal thyroid function.

\section{Declaration of interest}

The authors declare that there is no conflict of interest that would prejudice the impartiality of this scientific work.

\section{Funding}

This research did not receive any specific grant from any funding agency in the public, commercial or not-for-profit sector. 


\section{References}

1 Davies TF, Ando T, Lin RY, Tomer Y \& Latif R. Thyrotropin receptorassociated diseases: from adenomata to Graves disease. Journal of Clinical Investigation 2005115 1972-1983.

2 Laurberg P, Pedersen KM, Vestergaard H \& Sigurdsson G. High incidence of multinodular toxic goitre in the elderly population in a low iodine intake area vs. high incidence of Graves' disease in the young in a high iodine intake area: comparative surveys of thyrotoxicosis epidemiology in East-Jutland Denmark and Iceland. Journal of Internal Medicine 1991229 415-420.

3 Laurberg P, Nygaard B, Glinoer D \& Grussendorf M. Orgiazzi Guidelines for TSH-receptor antibody measurements in pregnancy: results of an evidence-based symposium organized by the European Thyroid Association. European Journal of Endocrinology $1998139584-586$.

4 Amino N, Tanizawa O, Mori H, Iwatani Y, Yamada T, Kurachi K, Kumahara Y \& Miyai K. Aggravation of thyrotoxicosis in early pregnancy and after delivery in Graves' disease. Journal of Clinical Endocrinology and Metabolism 198255 108-112.

5 Rotondi M, Cappelli C, Pirali B, Pirola I, Magri F, Fonte R, Castellano M, Agabiti Rosei E \& Chiovato L. The effect of pregnancy on subsequent relapse from Graves' disease following a successful course of anti-thyroid drug therapy. Journal of Clinical Endocrinology and Metabolism 200893 3985-3988.

6 Atkinson S, McGregor AM, Kendall-Taylor P, Peterson MM \& Smith BR. Effect of radioiodine on stimulatory activity of Graves' immunoglobulins. Clinical Endocrinology 198216 537-543.

7 Teng CS, Yeung RT, Khoo RK \& Alagaratnam TT. A prospective study of the changes in thyrotropin binding inhibitory immunoglobulins in Graves' disease treated by subtotal thyroidectomy or radioactive iodine. Journal of Clinical Endocrinology and Metabolism 198050 1005-1010.

8 Laurberg P, Wallin G, Tallstedt L, Abraham-Nordling M, Lundell G \& Tørring O. TSH-receptor autoimmunity in Graves' disease after therapy with anti-thyroid drugs, surgery, or radioiodine: a 5-year prospective randomized study. European Journal of Endocrinology 2008158 69-75.

9 Davis LE, Lucas MJ, Hankins GD, Roark ML \& Cunningham FG. Thyrotoxicosis complicating pregnancy. American Journal of Obstetrics and Gynecology $1989 \mathbf{1 6 0} 63-70$.

10 Millar LK, Wing DA, Leung AS, Koonings PP, Montoro MN \& Mestman JH. Low birth weight and preeclampsia in pregnancies complicated by hyperthyroidism. Obstetrics and Gynecology 1994 84 946-949.

11 Kriplani A, Buckshee K, Bhargava VL, Takkar D \& Ammini AC. Maternal and perinatal outcome in thyrotoxicosis complicating pregnancy. European Journal of Obstetrics and Gynecology 199454 159-163.

12 Mestman JH. Hyperthyroidism in pregnancy. Best Practice and Research. Clinical Endocrinology and Metabolism 2004 18 267-288.

13 Tamaki H, Amino N, Aozasa M, Mori M, Tanizawa O \& Miyai K. Serial changes in thyroid-stimulating antibody and thyrotropin binding inhibitor immunoglobulin at the time of postpartum occurrence of thyrotoxicosis in Graves' disease. Journal of Clinical Endocrinology and Metabolism 198765 324-330.

14 Glinoer D. The regulation of thyroid function in pregnancy: pathways of endocrine adaptation from physiology to pathology. Endocrine Reviews $1997 \mathbf{1 8}$ 404-433.

15 Momotani N, Noh J, Oyanagi H, Ishikawa N \& Ito K. Antithyroid drug therapy for Graves' disease during pregnancy. Optimal regimen for fetal thyroid status. New England Journal of Medicine $198631524-28$.

16 Kung AW \& Jones BM. A change from stimulatory to blocking antibody activity in Graves' disease during pregnancy. Journal of Clinical Endocrinology and Metabolism $1998 \mathbf{8 3}$ 514-518.

17 Ueta Y, Fukui H, Murakami H, Yamanouchi Y, Yamamoto R, Murao A, Santou Y, Taniguchi S, Mitani Y \& Shigemasa C.
Development of primary hypothyroidism with the appearance of blocking-type antibody to thyrotropin receptor in Graves' disease in late pregnancy. Thyroid 19999 179-182.

18 Amino N, Izumi Y, Hidaka Y, Takeoka K, Nakata Y, Tatsumi KI, Nagata A \& Takano T. No increase of blocking type antithyrotropin receptor antibodies during pregnancy in patients with Graves' disease. Journal of Clinical Endocrinology and Metabolism $2003 \mathbf{8 8} 5871-5874$.

19 Mandel SJ, Brent GA \& Larsen PR. Review of antithyroid drug use during pregnancy and report of a case of Aplasia cutis. Thyroid 19944 129-133.

20 Clementi M, Di Gianantonio E, Pelo E, Mammi I, Basile RT \& Tenconi R. Methimazole embryopathy: delineation of the phenotype. American Journal of Medical Genetics 199983 43-46.

21 Di Gianantonio E, Schaefer C, Mastroiacovo PP, Cournot MP, Benedicenti F, Reuvers M, Occupati B, Robert E, Bellemin B, Addis A, Arnon J \& Clementi M. Adverse effects of prenatal methimazole exposure. Teratology $200164262-266$.

22 Alexander EK, Marqusee E, Lawrence J, Jarolim P, Fischer GA \& Larsen PR. Timing and magnitude of increases in levothyroxine requirements during pregnancy in women with hypothyroidism. New England Journal of Medicine $2004351241-249$.

23 Momotani N, Ito K. Hamada N, Ban Y, Nishikawa Y \& Mimura T. Maternal hyperthyroidism and congenital malformation in the offspring. Clinical Endocrinology 198420 695-700.

24 Mandel SJ \& Cooper DS. The use of antithyroid drugs in pregnancy and lactation. Journal of Clinical Endocrinology and Metabolism $2001862354-2359$.

25 Dunn JT \& Delange F. Damaged reproduction: the most important consequence of iodine deficiency. Journal of Clinical Endocrinology and Metabolism 200186 2360-2363.

26 Zimmerman D. Fetal and neonatal hyperthyroidism. Thyroid 1999 9 727-733.

27 Hernandez A, Martinez ME, Fiering S, Galton VA \& St Germain D. Type 3 deiodinase is critical for the maturation and function of the thyroid axis. Journal of Clinical Investigation $2006116476-484$.

28 Nachum Z, Rakover Y, Weiner E \& Shalev E. Graves' disease in pregnancy: prospective evaluation of a selective invasive treatment protocol. American Journal of Obstetrics and Gynecology 2003 189 159-165.

29 Van Kamp IL, Klumper FJ, Oepkes D, Meerman RH, Scherjon SA, Vandenbussche FP \& Kanhai HH. Complications of intrauterine intravascular transfusion for fetal anemia due to maternal red-cell alloimmunization. American Journal of Obstetrics and Gynecology $2005192171-177$.

30 Thorpe-Beeston JG, Nicolaides KH \& McGregor AM. Fetal thyroid function. Thyroid 19922 207-217.

31 LaFranchi S. Thyroid function in the preterm infant. Thyroid 1999 $971-78$.

32 Weeke J, Dybkjaer L, Granlie K, Eskjaer Jensen S, Kjaerulff E, Laurberg P \& Magnusson B. A longitudinal study of serum TSH, and total and free iodothyronines during normal pregnancy. Acta Endocrinologica $1982101531-537$.

33 Burrow GN. Neonatal goiter after maternal propylthiouracil therapy. Journal of Clinical Endocrinology and Metabolism 196525 403-408.

34 Cheron RG, Kaplan MM, Larsen PR, Selenkow HA \& Crigler JF Jr. Neonatal thyroid function after propylthiouracil therapy for maternal Graves' disease. New England Journal of Medicine 1981 $304525-528$.

35 Van Loon AJ, Derksen JT, Bos AF \& Rouwé CW. In utero diagnosis and treatment of fetal goitrous hypothyroidism, caused by maternal use of propylthiouracil. Prenatal Diagnosis 199515 599-604.

36 Abuhamad AZ, Fisher DA, Warsof SL, Slotnick RN, Pyle PG, Wu SY \& Evans AT. Antenatal diagnosis and treatment of fetal goitrous hypothyroidism: case report and review of the literature. Ultrasound in Obstetrics and Gynecology 19956 368-371. 
37 Bruner JP \& Dellinger EH. Antenatal diagnosis and treatment of fetal hypothyroidism. A report of two cases. Fetal Diagnosis and Therapy 199712 200-204.

38 Ochoa-Maya MR, Frates MC, Lee-Parritz A \& Seely EW. Resolution of fetal goiter after discontinuation of propylthiouracil in a pregnant woman with Graves' hyperthyroidism. Thyroid 19999 1111-1114.

39 Gallagher MP, Schachner HC, Levine LS, Fisher DA, Berdon WE \& Oberfield SE. Neonatal thyroid enlargement associated with propylthiouracil therapy of Graves' disease during pregnancy: a problem revisited. Journal of Pediatrics 2001139 896-900.

40 Cohen O, Pinhas-Hamiel O, Sivan E, Dolitski M, Lipitz S \& Achiron R. Serial in utero ultrasonographic measurements of the fetal thyroid: a new complementary tool in the management of maternal hyperthyroidism in pregnancy. Prenatal Diagnosis 2003 23 740-742.

41 Lembet A, Eroglu D, Kinik ST, Gurakan B \& Kuscu E. Non-invasive management of fetal goiter during maternal treatment of hyperthyroidism in Graves' disease. Fetal Diagnosis and Therapy $200520254-257$.

42 Luton D, Le Gac I, Vuillard E, Castanet M, Guibourdenche J, Noel M, Toubert ME, Léger J, Boissinot C, Schlageter MH, Garel C, Tébeka B, Oury JF, Czernichow P \& Polak M. Management of Graves' disease during pregnancy: the key role of fetal thyroid gland monitoring. Journal of Clinical Endocrinology and Metabolism $2005906093-6098$.

43 Van Sande J, Costa MJ, Massart C, Swillens S, Costagliola S, Orgiazzi J \& Dumont JE. Kinetics of thyrotropin-stimulating hormone (TSH) and thyroid-stimulating antibody binding and action on the TSH receptor in intact TSH receptor-expressing $\mathrm{CHO}$ cells. Journal of Clinical Endocrinology and Metabolism $2003 \mathbf{8 8}$ 366-374.

44 Momotani N, Noh JY, Ishikawa N \& Ito K. Effects of propylthiouracil and methimazole on fetal thyroid status in mothers with Graves' hyperthyroidism. Journal of Clinical Endocrinology and Metabolism 199782 3633-3636.
45 Nøhr SB \& Laurberg P. Opposite variations in maternal and neonatal thyroid function induced by iodine supplementation during pregnancy. Journal of Clinical Endocrinology and Metabolism $200085623-627$.

46 Polak M, Legac I, Vuillard E, Guibourdenche J, Castanet M \& Luton D. Congenital hyperthyroidism: the fetus as a patient. Hormone Research 200665 235-242.

47 Matsuura N, Harada S, Ohyama Y, Shibayama K, Fukushi M, Ishikawa N, Yuri K, Nakanishi M, Yokota Y, Kazahari K \& Oguchi H. The mechanisms of transient hypothyroxinemia in infants born to mothers with Graves' disease. Pediatric Research 199742 214-218.

48 Abalovich M, Amino N, Barbour LA, Cobin RH, De Groot LJ, Glinoer D, Mandel SJ \& Stagnaro-Green A. Management of thyroid dysfunction during pregnancy and postpartum: an Endocrine Society Clinical Practice Guideline. Journal of Clinical Endocrinology and Metabolism 200792 S1-S47.

49 Srisupundit K, Sirichotiyakul S, Tongprasert F, Luewan S \& Tongsong T. Fetal therapy in fetal thyrotoxicosis: a case report. Fetal Diagnosis and Therapy 200823 114-116.

$50 \mathrm{McNab} \mathrm{T} \&$ Ginsberg J. Use of anti-thyroid drugs in euthyroid pregnant women with previous Graves' disease. Clinical and Investigative Medicine $2005 \mathbf{2 8} 127-131$.

51 Kempers MJ, van Tijn DA, van Trotsenburg AS, de Vijlder JJ, Wiedijk BM \& Vulsma T. Central congenital hypothyroidism due to gestational hyperthyroidism: detection where prevention failed. Journal of Clinical Endocrinology and Metabolism $2003 \mathbf{8 8}$ 5851-5857.

52 Kempers MJ, van Trotsenburg AS, van Rijn RR, Smets AM, Smit BJ, de Vijlder JJ \& Vulsma T. Loss of integrity of thyroid morphology and function in children born to mothers with inadequately treated Graves' disease. Journal of Clinical Endocrinology and Metabolism 200792 2984-2991.

Received 30 September 2008

Accepted 6 October 2008 